\title{
Front Matter: Volume 11813
}

, "Front Matter: Volume 11813," Proc. SPIE 11813, Tribute to James C. Wyant: The Extraordinaire in Optical Metrology and Optics Education, 1181301 (3 November 2021); doi: 10.1117/12.2606646

SPIE Event: SPIE Optical Engineering + Applications, 2021, San Diego, California, SPIE. United States 


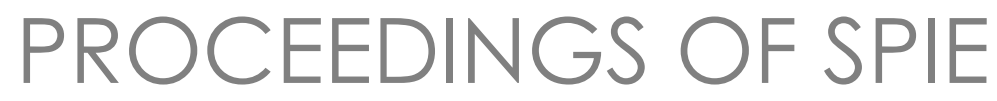

\title{
Tribute to James C. Wyant: The Extraordinaire in Optical Metrology and Optics Education
}

\author{
Virendra N. Mahajan \\ Daewook Kim \\ Conference Chairs/Proceedings Editors
}

2-3 August 2021

San Diego, California, United States

Sponsored by

SPIE

Cooperating Organizations

Wyant College of Optical Sciences (United States)

4D Technology Corporation (United States)

Optimax Systems, Inc. (United States)

Dr. Larry Johnson (United States)

Dr. John Hayes (United States)

Published by

SPIE 
The papers in this volume were part of the technical conference cited on the cover and title page. Papers were selected and subject to review by the editors and conference program committee. Some conference presentations may not be available for publication. Additional papers and presentation recordings may be available online in the SPIE Digital Library at SPIEDigitalLibrary.org.

The papers reflect the work and thoughts of the authors and are published herein as submitted. The publisher is not responsible for the validity of the information or for any outcomes resulting from reliance thereon.

Please use the following format to cite material from these proceedings:

Author(s), "Title of Paper," in Tribute to James C. Wyant: The Extraordinaire in Optical Metrology and Optics Education, edited by Virendra N. Mahajan, Daewook Kim, Proc. of SPIE 11813, Seven-digit Article CID Number (DD/MM/YYYY); (DOI URL).

ISSN: 0277-786X

ISSN: 1996-756X (electronic)

ISBN: 9781510644649

ISBN: 9781510644656 (electronic)

Published by

SPIE

P.O. Box 10, Bellingham, Washington 98227-0010 USA

Telephone +1 3606763290 (Pacific Time)

SPIE.org

Copyright @ 2021 Society of Photo-Optical Instrumentation Engineers (SPIE).

Copying of material in this book for internal or personal use, or for the internal or personal use of specific clients, beyond the fair use provisions granted by the U.S. Copyright Law is authorized by SPIE subject to payment of fees. To obtain permission to use and share articles in this volume, visit Copyright Clearance Center at copyright.com. Other copying for republication, resale, advertising or promotion, or any form of systematic or multiple reproduction of any material in this book is prohibited except with permission in writing from the publisher.

Printed in the United States of America by Curran Associates, Inc., under license from SPIE.

Publication of record for individual papers is online in the SPIE Digital Library.

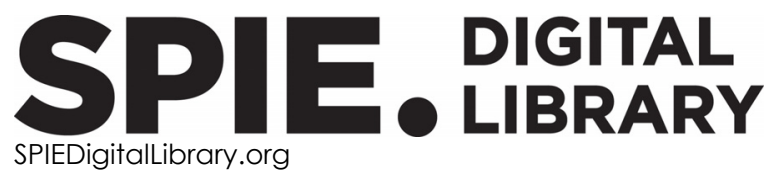

Paper Numbering: A unique citation identifier (CID) number is assigned to each article in the Proceedings of SPIE at the time of publication. Utilization of CIDs allows articles to be fully citable as soon as they are published online, and connects the same identifier to all online and print versions of the publication. SPIE uses a seven-digit CID article numbering system structured as follows:

- The first five digits correspond to the SPIE volume number.

- The last two digits indicate publication order within the volume using a Base 36 numbering system employing both numerals and letters. These two-number sets start with 00, 01, 02, 03, 04, 05, 06, 07, 08, 09, 0A, OB ... 0Z, followed by 10-1Z, 20-2Z, etc. The CID Number appears on each page of the manuscript. 


\title{
Contents
}

\author{
vii Authors \\ ix James C. Wyant: The Extraordinaire; Career and Awards \\ xiii Conference Chairs and Program Committee \\ xv Preface \\ INTRODUCTION
}

1181302 James C. Wyant: a Biography [11813-101]

SESSION 1 JAMES C. WYANT: THE EXTRAORDINAIRE (Virendra N. Mahajan, Chair)

1181303 James Wyant, east to west, industry to academia: a career of impact and innovation [11813-1]

1181304 Wyant: from academia to industry to academia [1 1813-2]

1181305 James C. Wyant: lighting the future [1 1813-3]

1181306 James C. Wyant: lessons from a master entrepreneur [11813-4]

SESSION 2 JAMES C. WYANT: THE LEADER (Daewook Kim, Chair)

1181308 Seeing fringes everywhere: impact of James C. Wyant's contributions to optical metrology [1 1813-7]

$1181309 \quad$ A career working with Jim Wyant [1 1813-37]

$118130 \mathrm{~A} \quad$ Celebrating the many contributions of Jim Wyant [11813-8]

SESSION 3 JAMES C. WYANT: THE EDUCATOR (Masud Mansuripur, Chair)

11813 OB Jim Wyant's impactful philanthropic strategy to advance higher education [11813-9] 
11813 OC Dr. Wyant: educator, expert, and entrepreneur [11813-10]

11813 OD The evolution of OPTI513 Optical Testing course at the Wyant College of Optical Sciences [11813-11]

11813 OE James C. Wyant: optical disciple, educator, physician, producer [1 1813-12]

$11813 \mathrm{OF} \quad 10.6$ micron interferometry and beyond [11813-13]

$118130 \mathrm{~J}$ James C. Wyant, my academic boss [11813-14]

SESSION 4 JAMES C. WYANT: THE METROLOGIST (John B. Hayes, Chair)

$11813 \mathrm{OH}$ If you can't measure it, you can't make it: the importance of metrology in optics fabrication Optimax's 30 year history [11813-16]

11813 Ol Ubiquity of Fourier transformation in optical sciences [11813-17]

$118130 \mathrm{~J} \quad$ Optical metrology: methodological analogy and duality revisited [1 1813-19]

11813 OK Computer-generated hologram for optical testing: a review [11813-18]

$11813 \mathrm{OL} \quad$ High-speed Fizeau interferometry and digital holography for dynamic phenomena measurement [1 1813-20]

SESSION 5 JAMES C. WYANT: THE INSPIRER (Hong Hua, Chair)

11813 ON Northern influence: how James Wyant helped grow the optics community in Montana [1 1813-24]

1181300 The surface PSD and image degradation due to mid-spatial-frequency errors [1 1813-25]

11813 OP Wavefront year for analyzing and testing in 2021 [11813-26]

SESSION $6 \quad$ JAMES C. WYANT: THE ENABLER (Joseph A. Shaw, Chair)

$118130 Q \quad$ Surface slope tolerances: the transition from geometric raytracing to scalar wave theory [1 1813-28]

11813 OR Many facets of interferometry: a deceptively simple and powerful measurement technique [1 1813-27]

$118130 S \quad$ Space-based camera systems [11813-30]

iv 
11813 OU High-speed interferometry for James Webb Space Telescope testing [11813-32]

$118130 \mathrm{~V}$ High-speed 3D imaging with digital fringe projection techniques [1 1813-33]

11813 OW Optics in wearable displays: James Wyant's influence on my professional career [11813-34]

$118130 \mathrm{X}$ James Wyant's contributions to polarization aberration theory [11813-6] 
Proc. of SPIE Vol. $118131181301-6$

Downloaded From: https://www.spiedigitallibrary.org/conference-proceedings-of-spie on 26 Apr 2023
Terms of Use: https://www.spiedigitallibrary.org/terms-of-use Terms of Use: https://www.spiedigitallibrary.org/terms-of-use 


\section{Authors}

Numbers in the index correspond to the last two digits of the seven-digit citation identifier (CID) article numbering system used in Proceedings of SPIE. The first five digits reflect the volume number. Base 36 numbering is employed for the last two digits and indicates the order of artic les within the volume. Numbers start with 00, 01, 02, 03, 04, 05, 06, 07, 08, 09, 0A, 0B...0Z, followed by 10-1Z, 20-2Z, etc.

Brock, Neal, 09

Brooks, Lawrence D., OE

Brown, Thomas G., 03

Camey, P. Scott, 03

Chipman, Russell A., OX

Creath, Katherine, 08

Feinberg, L., OU

Goldstein, Goldie, 08

Goodman, J oseph W., OA

Graves, Logan R., OC

Han, Sen, OP

Harvey, James E., 00

Hayes, J ohn B., 06

Hua, Hong, OW

J ackin, J essie, OL

Johnson, Lawrence A., ON

Keski-Kuha, R., OU

Kim, Da ewook, OD

Kiyohara, Kosuke, OL

Koch, Thomas L., 05

Kwon, Osuk Y., OF

Mahajan, Virendra N., OG

Mandina, Michael P., $\mathrm{OH}$

Mansuripur, Masud, ol

Millerd, J a mes, 09

Nelson, J essica DeGroote, $\mathrm{OH}$

Novak, Erik, 09

Onuma, Takashi, OL

Orr, Tammy, 02

Otani, Yukitoshi, OL

Plympton, Ric hard, $\mathrm{OH}$

Rogers, J ohn R., 0Q

Rowan, Kaye, OB

Sa if, B., OU

Sc hmit, J oa nna, 08

Shannon, Robert R., 04

Shaw, J oseph A., ON

Shibata, Syuhei, OL

Smith, Peter H., OS

Strojnik, Ma ija, OR

Takeda, Mitsuo, 0J

Trumper, Isaac L, OC

Yatagai, Toyohiko, OL

Zhang, Song, OV

Zhao, Chunyu, OK 
Proc. of SPIE Vol. 11813 1181301-8 Downloaded From: https://www.spiedigitallibrary.org/conference-proceedings-of-spie on 26 Apr 2023
Terms of Use: https://www.spiedigitallibrary.org/terms-of-use 


\section{James C. Wyant}

\section{The Extraordinaire}

Career and Awards

Proc. of SPIE Vol. $118131181301-9$ 


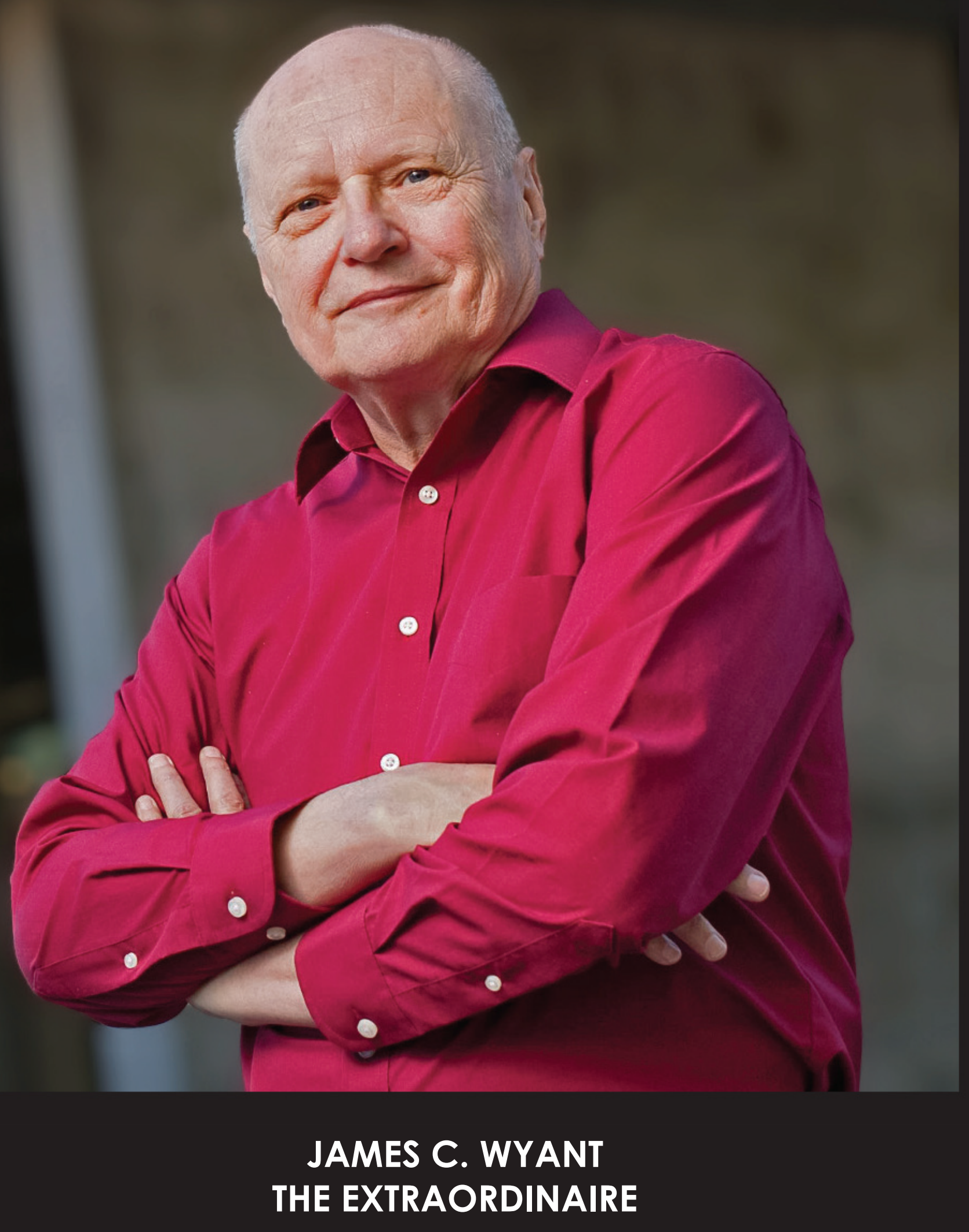




\title{
James C. Wyant
}

James C. Wyant is professor emeritus at the College of Optical Sciences at the University of Arizona where he was Director (1999-2005) and Dean (2005-2012). He received a B.S. in physics from Case Western Reserve University and M.S. and Ph.D. in optics from the University of Rochester.

\section{CAREER}

Wyant was a founder of the WYKO Corporation and served as its president and board chairman from 1984 to 1997. He was also a founder of the 4D Technology Corporation and currently serves as its board chairman. Wyant is a member of the National Academy of Engineering, a Fellow of OSA (Optical Society of America),

SPIE (International Society of Optics and Photonics), and Distinguished Fellow OSI (Optical Society of India), an honorary member of the Optical Society of Korea, and former editor-in-chief of the OSA journal Applied Optics. He was the 2010 president of OSA and the 1986 president of SPIE. In April of 2019, the College of Optical Sciences at the University of Arizona was renamed to be the James C. Wyant College of Optical Sciences in his honor.

\author{
AWARDS \\ Accountabillt Lifetime Achievement Award from the Arizona \\ Technology Council \\ Arizona's "Innovator of the Year" Product Award \\ Arizona Technology Council William F. McWhortor Award \\ Doctorado Honoris Causa from the Instituto Nacional de Astrofisica, Optica y \\ Electronica in Puebla, Mexico \\ Honorary Doctor of Science Degree, University of Rochester \\ OSA Joseph Fraunhofer Award \\ SPIE Chandra Vikram Award \\ SPIE Gold Medal \\ SPIE Technology Achievement Award \\ SPIE Visionary Award \\ Tom Brown Excellence in Entrepreneurship Award \\ University of Arizona Technology Innovation Award \\ University of Rochester College of Engineering Distinguished Alumnus Award
}


Proc. of SPIE Vol. 11813 1181301-12

Downloaded From: https://www.spiedigitallibrary.org/conference-proceedings-of-spie on 26 Apr 2023 Terms of Use: https://www.spiedigitallibrary.org/terms-of-use 


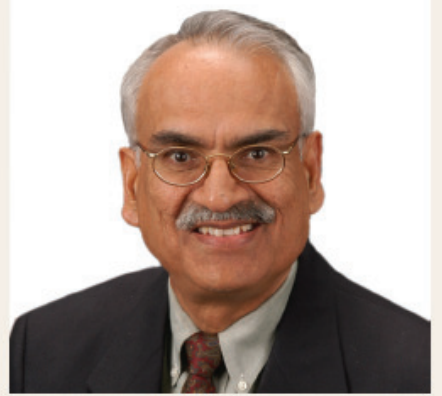

Virendra N. Mahajan

Wyant College of Optical

Sciences (United States)

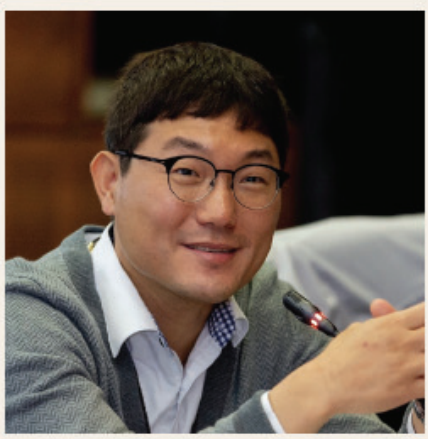

\section{Daewook Kim}

Wyant College of Optical

Sciences (United States)

\section{PROGRAM COMMITTEE}

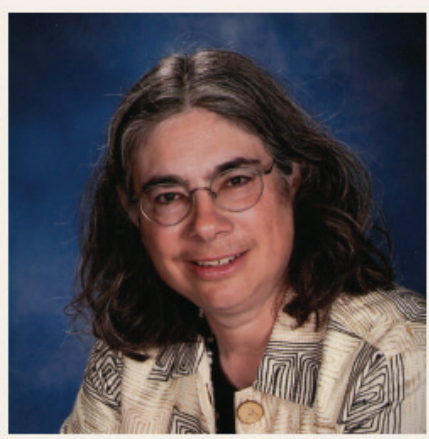

\section{Katherine Creath}

Optineering

(United States) and

Wyant College of

Optical Sciences

(United States)
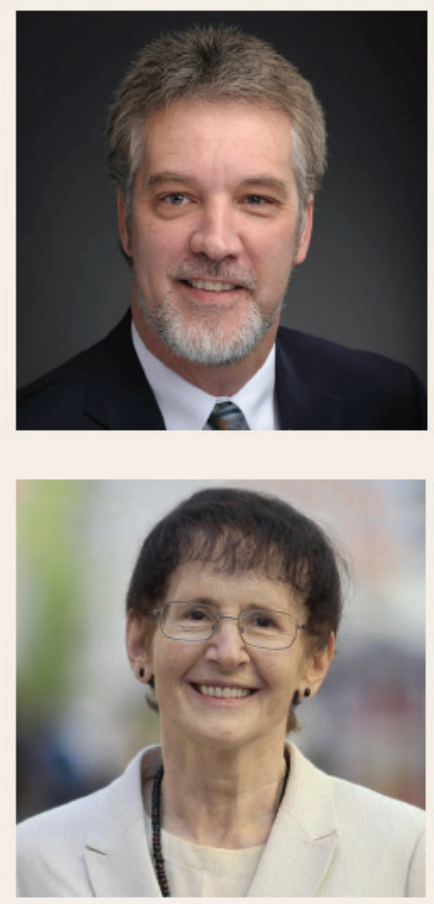

Joseph A. Shaw

Montana State Univ.

(United States)

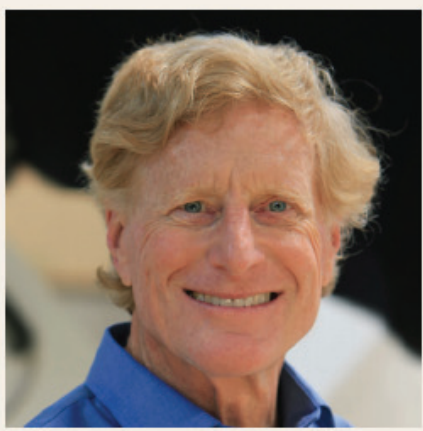

\section{John B. Hayes}

Wyant College of Optical Sciences (United States)

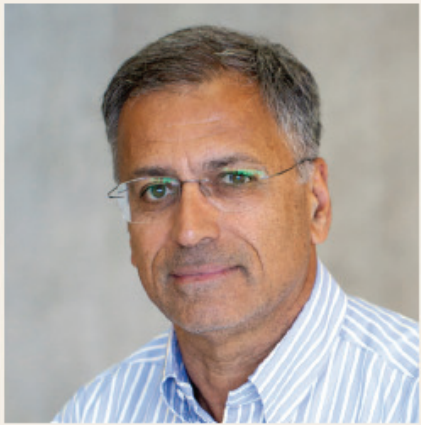

Masud Mansuripur

Wyant College of Optical Sciences (United States)

\section{Marija Strojnik}

Centro de Investigaciones en Óptica, A.C. (Mexico) 
Proc. of SPIE Vol. 11813 1181301-14

Downloaded From: https://www.spiedigitallibrary.org/conference-proceedings-of-spie on 26 Apr 2023 Terms of Use: https://www.spiedigitallibrary.org/terms-of-use 


\section{Preface}

It has been a great honor for us to work on this Tribute to James C. Wyant, The Extraordinaire in Optical Metrology and Optics Education. It was in the making for two years starting from an idea and initiation to execution and producing the SPIE Proceedings. Our first step was to get Jim's okay to hold a tribute for him, get Kent Rochford's agreement for SPIE sponsorship, and Dean Tom Koch to give his blessings. Once that was done, we prepared a Call for Papers for SPIE which they announced in December 2019 for a tribute celebration conference at SPIE Optics + Photonics in San Diego in August 2020. We sent invitations to all of Jim's former students and professional colleagues to present their tribute papers. We prepared slightly different invitations for different groups such as Jim's professional colleagues, his former PhD and MS students, and some special invitees.

Because Jim had been retired since 2014, we did not focus on technical presentations at the tribute. We encouraged contributors instead to focus on how Jim had impacted their lives and present accolades attributed to him. In short, we wanted the tribute to be a fun and joyful event. Thus, from the outset, our emphasis was on recollections and reflections of experiences with Jim. Of course, people were also free to present technical papers on any of the topics that were outlined in the Call for Papers.

Since we wanted to make sure that the event was not based solely on our thinking, we formed a program committee by inviting some of our colleagues to participate as members. Four of them are graduates of the College of Optical Sciences and the fifth is a faculty member. Some international perspective was added by one of the four who is a Slovenian American working in Leon, Mexico at the Centro de Investigaciones en Óptica, A.C. $(\mathrm{ClO})$. Of course, we ourselves are also graduates of the same College.

We received over 30 abstracts, mostly from Jim's professional colleagues and his former students, but a few from others. We divided the papers into 7 sessions each under the title of a specific characteristic of Jim and allotted each speaker 15 minutes, but only 10 minutes each to ourselves over a two-day period. The characteristics include the Extraordinaire, Leader, Educator, Metrologist, Inspirer, Enabler, and Futurist. Because most of the speakers were in the invited and, therefore, guest category, we had a strong desire to hold a dinner for all. A dinner gathering would also provide an opportunity for Jim to thank the speakers for their participation.

As we began working on the details of our tribute program, we also started wondering if we will be able to hold the tribute in August 2020 as planned, because of the growing concern over the looming COVID-19 pandemic. Once SPIE decided that $\mathrm{O}+\mathrm{P}$ would be a digital forum, it became clear that we would 
have to postpone the tribute for a year. We felt strongly that a tribute by its very nature should be held in person. After careful discussions with the program committee members and checking with Jim, we decided to postpone the tribute to August 2021. We announced the postponement in the $\mathrm{O}+\mathrm{P} 2020$ meeting program and in the Watts Up Newsletter of the Wyant College. By then, we had plenty of papers so there was no need to solicit more, and we transferred all abstracts to the SPIE August 2021 meeting.

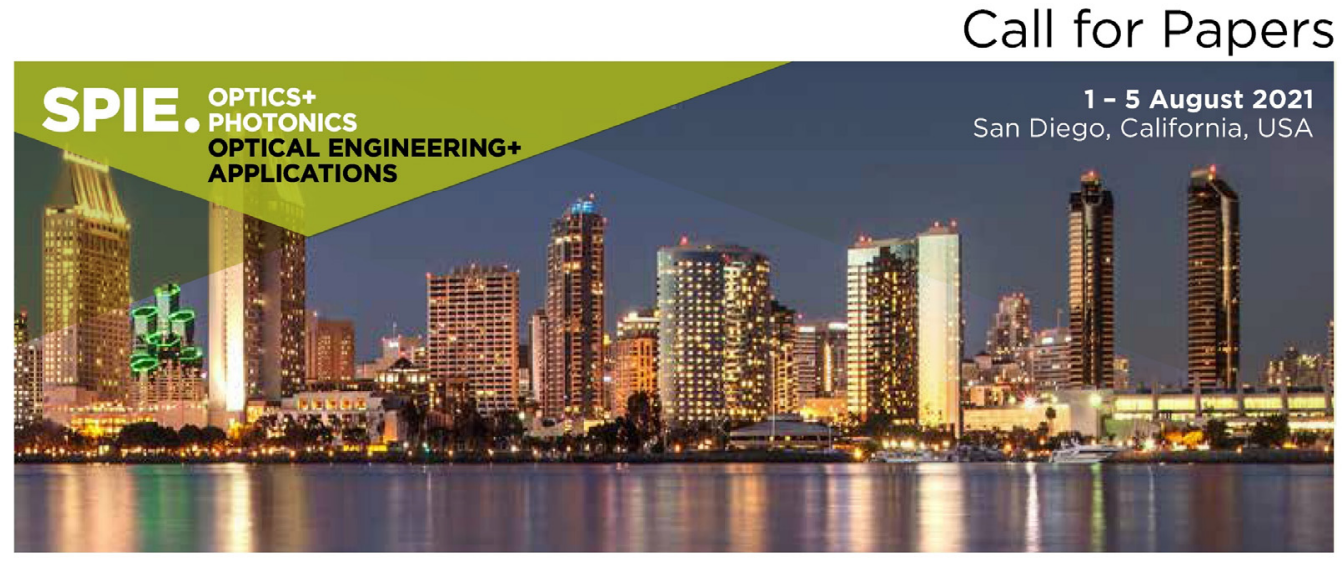

Tribute to James C. Wyant: The Extraordinaire in Optical Metrology and Optics Education (OP301)

Conference Chairs: Virendra N. Mahajan, Wyant College of Optical Sciences (USA); Dae Wook Kim, Wyant College of Optical Sciences (USA) Program Committee: Katherine Creath, Optineering (USA); John B. Hayes, 4D Technology Corp. (USA); Masud Mansuripur, Wyant College of Optical Sciences (USA); Joseph A. Shaw, Montana State Univ. (USA); Marija Strojnik, Centro de Investigaciones en Óptica, A.C. (Mexico)

This conference is dedicated to celebrate Professor and Dean James C. Wvant's extraordinary contributions and services to the fields of optical metrology and optics education. The focus of his research has been on applying the science of interferometry to precision metrology and sensing applications in various fields including computer-generated holograms, data storage, wavefront sensors for adaptive optics, optical fabrication, and optical system engineering.

Authors should submit papers they believe have been inspired or enabled by Jim's work. It is an opportunity to tell him how their lives have been impacted by their coming in contact with him. Anecdotal experiences and observations relating him to their work and life are encouraged.

Suggested topics for papers include, but are certainly not limited to:

- Applied interferometry, holography, and speckle

- Applications: phase-measuring, interferometric fringe analysis

- Absolute calibration: flats, spheres, windows, etc.

- Measurement of aspheres and freeforms

- Diffractive/Holographic null correctors: computer generated hologram

- Wavefront sensors

- Figure, ripple, and roughness: power spectral density measurement and

analysis

- Mid-spatial-frequency optics errors: detection, characterization, effects,

and mitigation

- Testing in adverse environments: vibration, atmosphere, cryogenic,

vacuum, etc

- Subsurface damage: detection, characterization, effects, and mitigation

- Surface profilometry: optical and scanning probe 
We held program committee meetings on Zoom to work out the details of the tribute program and producing hardcover edition of the Tribute Proceedings. Because SPIE was not planning to produce their usual hardcopy book of the $O+P$ meeting program, we discussed preparing a special tribute program brochure. Working closely with the organizers, SPIE staff prepared a beautiful program brochure. We decided to request the speakers who may not be able to present their papers in person to send their recorded presentations in advance so that we could show them during their scheduled place in the program. The hybrid format helped to keep the flow of the presentations in line with the program schedule.

The Tribute conference was very well attended on each of the two days, the 2nd and 3rd of August 2021. Our guest of honor, Jim, stayed in the conference room and attentively listened to each presentation. We knew that Professor Robert R. Shannon had submitted his manuscript but did not plan a video presentation, so we went to the next best person to speak in his place. We were so relieved and pleased when Jim agreed to do so. He told some amazing stories about working with Bob and how he influenced Jim's life. His memorable talk about his relationship with Bob was enjoyed by everyone.

To get community support for the tribute dinner, we called a couple of optics companies, and they happily agreed to contribute. We designated Dr. John Hayes, who was not only a former student of Jim but also his business partner, as our finance manager, and he reluctantly accepted the bestowed honor. He and Larry Johnson immediately volunteered to contribute to the dinner fund. John also got a commitment from Dean Tom Koch of the Wyant College to help fund the dinner and publication of a special edition of the Tribute Proceedings. Before we finished collecting funds, we asked SPIE if they would also fund the dinner. They graciously offered to host a tribute luncheon. An excellent buffet luncheon was held at Marina G. Hall in the Marriott Marquis Hotel. Jim thanked some 40 guests at the luncheon.

We asked Tammy Orr, the Wyant College historian, to write a short biography of $\mathrm{Jim}$ to show not only who he is but also relate where he had come from. When the Tribute conference was postponed to August 2021, she published the biography she had written in the OSC Website. She updated it some for the Tribute Proceedings, which now appears as the leading article followed by the papers written by those who spoke at the Tribute in the same order as in the scheduled program. 


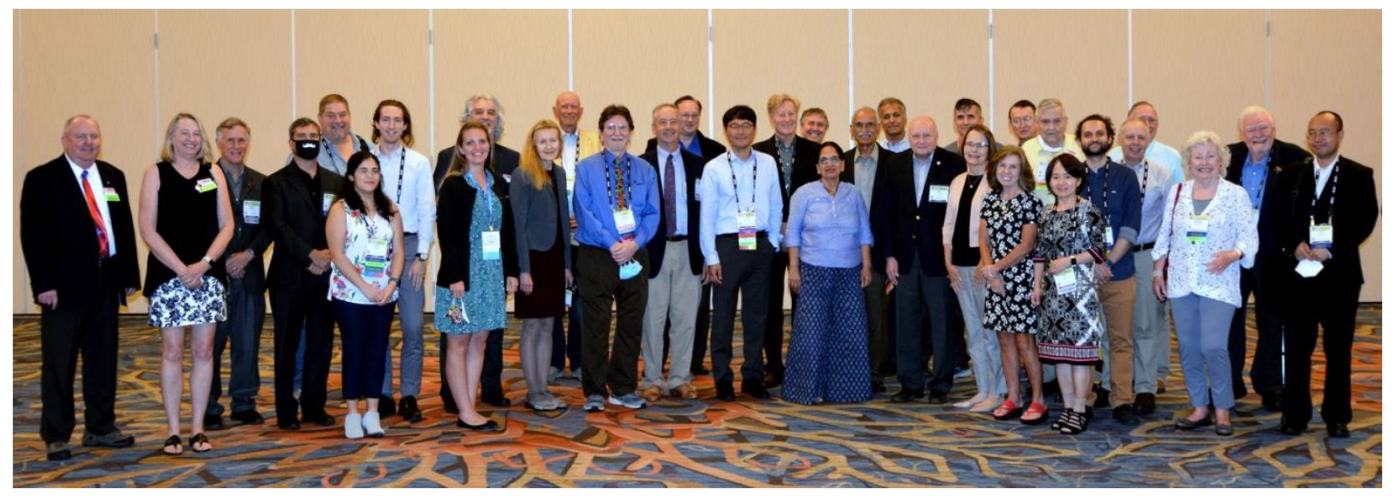

Wyant Tribute Luncheon Participants on 3 August 2021

(From left to right) John E. Greivenkamp, Kay Greivenkamp, Thomas G. Brown, Rick Plympton, Jim Schwiegerling, Clarissa M. DeLeon, Isaac L. Trumper, Jessica DeGroote Nelson, Joseph A. Shaw, Ritva A. Keski-Kuha, Peter H. Smith, Ray Williamson, Thomas L. Koch, Brent C. Bergner, Daewook Kim, John B. Hayes, Kent Rochford, Shashi Mahajan, Virendra Mahajan, Masud Mansuripur, James C. Wyant, José Sasián, Tammy Orr, Kaye Rowan, Russell A. Chipman, James B. Breckinridge, Hong Hua, Siddhartha Sirsi, Elliot Eichen, James E. Harvey, Karola Schumann, Jack Schumann, Chunyu Zhao

We are grateful to John for managing the finances, Tammy Orr for writing Jim's biography, Kaye Rowan for collecting and providing addresses of the invitees, Melissa Griffiths for mailing the invitations, Amee Hennig for announcing the Wyant Tribute in the OSC Watts Up Newsletter, Matt Novak for his constant support for the Tribute activities, Carrie Binschus for designing the Tribute Program brochure, and Nicole Harris for compiling the tribute Proceedings Volume. We also thank the tribute speakers for their participation and all who attended this tribute to honor Jim Wyant.

Virendra N. Mahajan Adjunct Professor

Daewook Kim

Associate Professor

James C. Wyant College of Optical Sciences The University of Arizona Conference Chairs and Proceedings Editors 